\title{
A LINGUAGEM DAS ORAÇÕES
}

OSWALDO PINHEIRO DOS REIS

Fac. Filosofia da Univ. do Paraná

As oraçōes apresentam aspectos peculiares dignos da atenção dos filólogos.

São consideradas, sob o ponto de vista lingüistico, fórmulas fixas de conversação com Deus e os seus santos. Para as pessoas que não têm fé não passam elas disso. E não só para os incrédulos: os brâmanes criaram os famosos moinhos de orações que nāo são mais que fonógrafos de palavras ocas, pois que desajudadas de sentimento. Pensam com isso comover seu deus que se mostra por tal forma muito pouco exigente. Nós também, pela distração, muitas vêzes não passamos de meros recitadores dos textos religiosos, uns - brâmanes cá a nosso modo.

Nas orações fundamentais do cristão (Padre Nosso, Ave-Maria, Credo, Em nome do Padre) numerosos são os latinismos ou semi-latinismos muito fàcilmente explicáveis. E', a língua do Lácio, o idioma oficial da lgreja desde o séc. III, desde aquêle edito de Teodósio que obrigava todos os povos do Império a confessar "a fé de Pedro". E até bem alta Idade Média continuavam os pregadores a fazer suas homilias em latim e a recitação das orações na mesma língua. Essa tradição, quanto às orações, mantém-se ainda muito forte em países românicos, especialmente na Itália, onde se ouvem imprecações públicas populares na fórmula original latina.

Os elementos semi-eruditos, românicos, são em grande número resultantes da influência eclesiástica e, por vêzes também, da organização jurídica.

O critério fonético os diferencia, para logo, das vozes de cunho popular. 
Também aí se colhem exemplos de latinismos sintáticos e semânticos apreciáveis.

Como em fórmulas estereotipadas, natural será que nas orações encontremos vestígios de arcaísmos e modos de dizer que trazem consigo algo daquela vetustez augusta da língua clássica, dos tempos que lá se foram envoltos no saudosismo dos amantes do passado.

Lembramos a prece mais importante do Cristianismo, a oração dominical, cujas palavras repassadas do mais bondoso coração paternal brotaram dos lábios do Mestre para os espíritos rudes de seus apóstolos.

Nela assinalarei apenas uns poucos casos. $O$ assunto, muito vasto, requer sobriedade:

1. Padre é como quem diz pai. Já existem pessoas que substituem, nas suas preces, aquela palavra por esta. $O$ seu aspecto denuncia semi-eruditismo. Sente-se logo que se acha mais próxima da sua fonte do que o vocábulo pai. Mas não é sòmente o seu traje fonético senão que o seu significado. Padre, na língua atual, assumiu um sentido especial de "pai espiritual" dentro da organização eclesiástica. Portanto, encontramo-nos em face de um arcaísmo fonético e semântico.

Quanto à palavra pai, dela decorrente, e de uso comum na língua cotidiana, ainda não se encontrou explicação suficiente para a sua evolução. Julgo ruim a de Leite de Vasconcelos atribuindo-a à linguagem infantil: Padre $>$ pade $>$ pae, pai. Que pensar então dos que a querem tirar ao provençal? . . O mesmo têrmo padre ocorre ainda na oração "do nome do Padre": Em nome do Padre, etc.

2. A ordem gramatical nas petições: Costuma-se ensinar que, com o desaparecimento dos casos, passou a imperar o morfema de colocação. E que, sob êste aspecto, a ordem direta (Sujeito - verbo - complementos) constitui a ordem normal da disposição dos elementos da frase. Seja. Para nós, porém, se nos afigura que o gênio da língua portuguêsa que se revela no seu esplendor estilistico, transparece muito mais na chamada ordem inversa. Inverter os elementos da proposição é aproximar a lín- 
gua de suas fontes, é manter a sua tradição histórica. Bem sei que tais conceitos não se aplicam a línguas cujos morfemas desinenciais se obliteraram, fonèticamente, como é o caso do francês. Exemplifiquemos com ambas as línguas e com a oração que comentamos:

Se em francês dizemos: "que votre nom soit sanctifié", em português rezaremos: "santificado seja o vosso nome" (cp. lat. sanctificetur nomen tuum); fr.: "que votre règne arrive", mas port.: "venha a nós o vosso reino" (cp. lat. adveniat regnum tuum); fr.: "que votre volonté soit faite", mas port.: "seja feita a vossa vontade" (cp. lat. fiat voluntas tua), etc..

3. O caso do emprêgo do infinito flexionado: A melhor regra, a mais prática, a mais cômoda é a de Soares Barbosa. Sempre me repugnou andar embrulhado nas 32 regras do Carlos Góis. como os judeus atrapalhados nos seus longos filactérios. $E$ falei da melhor, porque se bem que saiba se trate de duas, as duas na aritmética daquele português inteligente (o que não constitui exceção) transformam-se numa sòmente.

E' a regra muito conhecida da disparidade ou conformidade dos sujeitos da oração regente e da oração infinitiva. Mas, como tôda boa regra gramatical, admite lá suas exceções. Uma delas se observa quando o verbo regente é mandar, deixar, etc. Não é novidade. Aqui mesmo, no Padre Nosso, temos um exemplo assinalável: "Não nos deixeis (vós), cair (nós) em tentação", opõe-se frontalmente à regra do padre-gramático luso e vai encaixar-se na aludida exceção.

4. O emprêgo da adversativa - Ela introduz proposição cujo sentido se opōe ao da principal: Estudou, mas não aprendeu. Entretanto, no "Padre Nosso" encontramos: "Não nos deixeis cair em tentação mas livrai-nos do mal". Parece que se deveria dizer: "e livrai-nos do mal", para que essa coordenada se situasse bem na sequiência semântica do periodo. Acresce observar que a adversativa já se encontra no latim: "sed libera nos a malo". Como explicá-la? Por aí. Sed, em latim, emprega-se ordinàriamente depois de um membro de frase negativo (ne nos inducas...) para exprimir uma oposição positiva. Note-se bem: positiva. E' de ver, portanto, que se trata de um latinismo. 
A mina se nos apresenta feracissima. Essas notas não passam de uma pequena amostra do seu rico filão. Quem quiser pesquisar, muito mais encontrará.

Mas... estou aqui pensando naquele conto do Lobato, " $\mathrm{Ca}$ belos compridos", cujo tema era a inteligência curta de uma certa Das Dores. Para obedecer a um missionário - segundo o qual cada palavra das orações cotidianas devia ser meditada — pôs-se à noite fazer tão longas associações de idéias (totalmente ausentes do assunto religioso) que acabou por achar que o missionário dissera uma bobagem.

Vá calando também o articulista antes que um ruminador qualquer de assuntos gramaticais the assaque igual pecha.

(Transcrito de "Nosso Idioma", Fortaleza, Ce., n. 15, dez. de 1954). 